\title{
Preservation of vernacular schist masonry farm walls
}

\author{
C.E. Barroso, D.V. Oliveira \& L.F. Ramos \\ ISISE, University of Minho, Guimarães, Portugal
}

\begin{abstract}
This paper complements the information presented at the CIAV2013 on vernacular buildings in northern Portugal, and addresses the topic of masonry walls in the rural areas of the northwestern Portuguese coastline. These walls are structural schist masonry constructions, built using ancient techniques and locally available resources. The result is a territory built for agricultural exploration, and a landscape imprinted with past social hierarchies and structures. Using the information gathered by the fieldwork study, the paper will present studies on masonry walls with different morphologies, construction materials and building techniques employed. The information presented aims to contribute to enlighten researchers and technicians about these building specificities, to increase the scarce available literature about schist's potential as construction material, and to enhance the importance of the cultural value of this particular kind of heritage.
\end{abstract}

\section{THE VERNACULAR MASONRY WALL}

The vernacular masonry walls represent one of the most characteristic and important heritage of the Portuguese rural landscape. Built since immemorial times using empirical knowledge, by local populations and using locally available resources, they were used to establish limits, do define property boundaries, but also to shape and improve the landscape, making it more suitable for agricultural and forestall production. The Portuguese northwestern countryside along the Atlantic coastline, also called riverside (Saraiva 1994), see Figure 1, is characterized by large plains, valleys and smooth elevation transitions, but also by its dense occupation marked by a past strict social and economical hierarchy. Small and medium size farms and property passed to the territory the existent social organization, by the overwhelming presence of vernacular masonry walls in the landscape.

In the border between the Portuguese northeastern territory the riverside becomes the mountain (Saraiva 1994), see Figure 1, and the territory takes the shape of very steep mountains, with drastic elevation variations and very narrow and deep valleys. In this territory, fertile land is scarce and resource optimization is a priority, making collective work and the community vitals to the survival of local populations. In this territory, vernacular masonry walls are mainly used to establish areas and paths, to guard and control herds, and specially to help shaping the land in order to get more usable farmland.

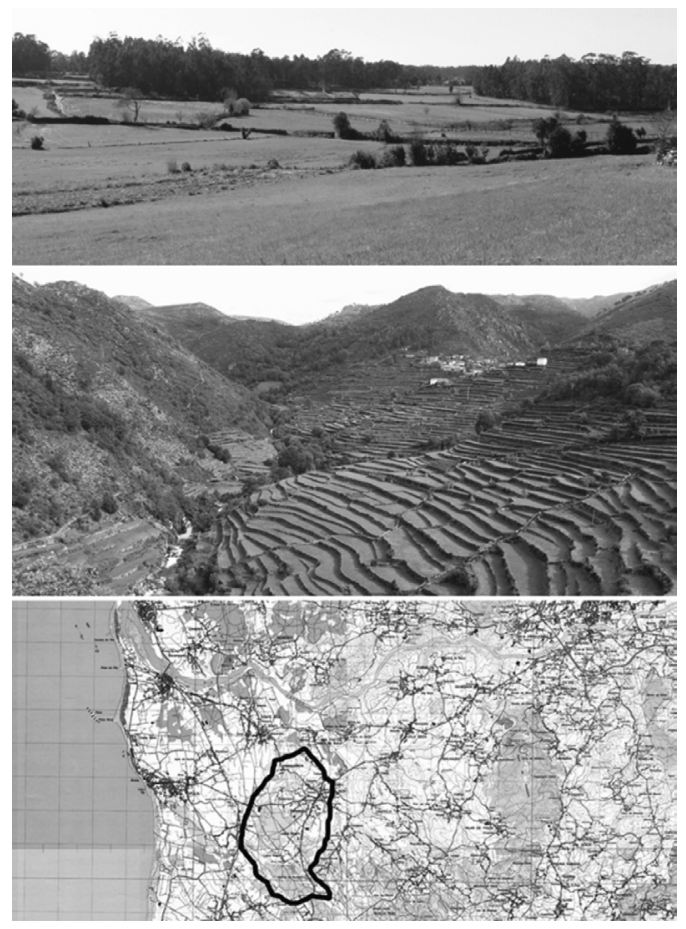

Figure 1. From the top: riverside rural landscapeBarqueiros, Barcelos (study area) $\left(41^{\circ} 29^{\prime} 6.46^{\prime} \mathrm{N}\right.$, $8^{\circ} 43^{\prime} 43.43$ "W); mountain rural landscape-Sistelo, Arcos de Valdevez $\left(41^{\circ} 58^{\prime} 54.88^{\prime}\right.$ N, $8^{\circ} 21^{\prime} 7.09^{\prime}$ 'W); Study area's limits on Portuguese military chart (C.E. Barroso et al.). 


\section{STUDY AREA CHARATERIZATION}

The study area, see Figure 1, is located in the south riverside area of the Cávado river, and its characterized by abundance of fertile land and of water resources, plateaus, valleys and plains extending until the Atlantic ocean. Until the mid-20th century, this area was exclusively a rural landscape densely explored by it agricultural resources, and occupied by small settlements composed either by more concentrated groups of farmhouses around a church or monastery, or by scattered groups over the territory.

In an effort to increase available resources, the farmland was prepared during centuries to increase its production capability by adding forestall materials and manures to the land, but also by the removal of natural limits by building slopes, of irrigation systems and production buildings.

With the increase of agricultural production occurred over the 19th century (Ribeiro 1945), along with the economical resources brought by the brasileiros emigrants (Monteiro 2000), and the construction of new regional roads connecting major cities, this territory gained in population and in wealth. It declined again in the first decades of the 20th century, leading in the $60 \mathrm{~s}$ and $70 \mathrm{~s}$ to an exponential growth of emigration phenomenon (Saraiva 1994). This new and very different emigration phenomenon to the center of Europe, imported different ways of life and vernacular logics and hierarchies were progressively abandoned.

\section{FIELDWORK}

The information gathered in this paper was collected and analyzed during the fieldwork presented at CIAV2013 International Conference (Barroso et al. 2013). The data was gathered by on-site observation and through geometrical and photographic surveys, interviews and the support of information from several rural studies and researches performed until the 1960s (Barroso, 2012).

\section{VERNACULAR MASONRY WALLS TYPOLOGIES}

The masonry walls in the study area were mainly built to perform two main functions, either to define limits between different functional areas of the same property or between different properties, or to protect private property from external threats. These walls could vary in height between very small height walls of just $0.4 \mathrm{~m}$ to $1.5 \mathrm{~m}$, been smaller and with dry joints masonry in forestall areas, and in ordinary masonry in all other cases. Local vernacular masonry walls presented sections of around $0.4 \mathrm{~m}$ to $0.6 \mathrm{~m}$ wide depending on their height, with very shallow foundation or just the extension of the masonry to the ground, and capstones.

The smaller masonry walls ( $0.4 \mathrm{~m}$ to $1 \mathrm{~m}$ high), see Figure 2, were very frequent in forestall properties and in defining functional areas within farmhouses' complexes like the threshing floor's limits or cattle enclosure inside farms. Average height masonry walls ( $1 \mathrm{~m}$ to $1.5 \mathrm{~m}$ high), see Figure 2, were mainly built to establish the limits between different farms. These walls had better construction quality and were also used to separate farmland from public property like secondary roads.

If visual and intrusion protection were the main concerns, high masonry walls were built ( $1.5 \mathrm{~m}$ to over $2.5 \mathrm{~m}$ high), see Figure 2, particularly from the 19 th century onwards, beneficiating from the good economical moments at the time. These walls were more elaborated and with superior quality buildings, that required a good economical capability,
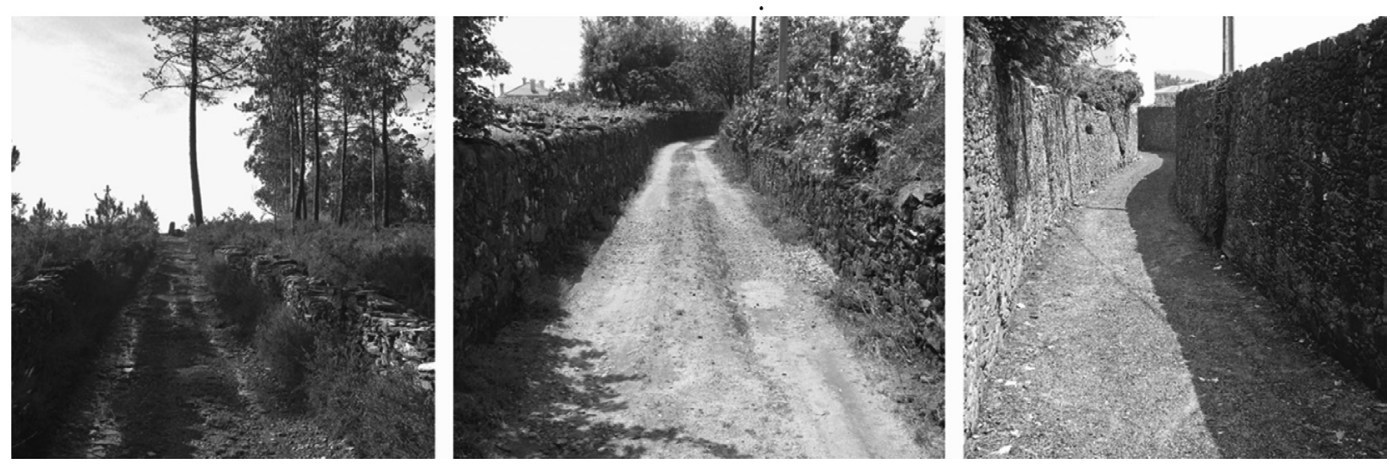

Figure 2. Examples of different masonry wall's morphologies. From left to right: small dry joints masonry wall in forestall area; average height masonry walls along rural road; high masonry walls along main road (C.E. Barroso et al.). 
specialized workers and ashlar stones for openings and turnings' reinforcement.

They presented a shallow foundation, a good quality fabric to the public space but with inferior fabric's quality to the property side, and also good quality and elaborated capstones with different shapes. Due to the increase quality of these high masonry walls, in a resource optimization effort, it was frequent to integrate them in new buildings like sheds or cattle facilities.

When needed, these higher walls were also used for vineyards' support inside the farm or over less important roads, by placing masonry supports on the capstones. The vernacular masonry walls studied were also used to help shape the territory. In order the cultivate maize or cultures that required constant irrigation or simply to increase the available production area, supporting terrace masonry walls were also built. These walls were solid constructions, built using the same techniques and larger masonry units that, depending on the height of land to retain, could also function as protection or division wall.

In the study area, it was also frequent the integration of the existent masonry walls in water irrigation systems. For this, a special masonry carved channel substituted the common capstone, and by giving the wall a continuous slope from the reservoir or well to the irrigation points or final reservoir, water would flow over the masonry walls and between the different farms.

\section{MATERIALS AND CONSTRUCTION}

The local schist stone, natural sands and clays were the main building materials used in the studied vernacular masonry walls (Barroso 2012). Schist stone was easily obtained because of its high availability, either at superficial level or extracted in shallow quarries. It had a simplified extraction process from the bedrock, and due to its inferior hardness compared with granites and its lamellar internal structure, it was easy to work.

Depending on its formation process, sedimentary or metamorphic, and on its mineralogical composition (Costa 2008), local schist presented a great diversity of superficial textures more or less smooth, and colors diversity from ochre, to red or grays.

Local schist also presented a large water absorption capability from the surrounding environment, and sensitivity to salt crystallization and climate damage. Schist's internal anisotropy affects considerably its load resistance performance, as it presents a better performance to loads applied along the direction normal to its anisotropy planes, and inferior in all other directions (Barros et al. 2014).
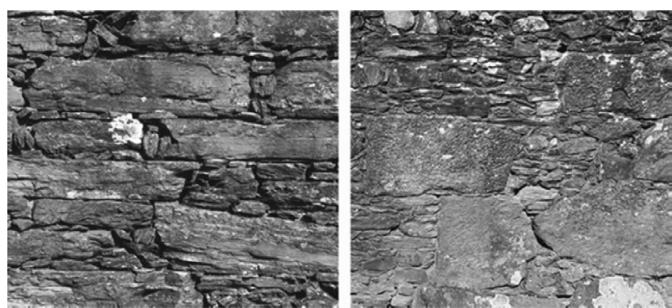

Figure 3. From left to right: Type 1 schist masonry fabric; Type 2 schist masonry fabric (C.E. Barroso et al.).

Attending to the masonry and stones observed during the fieldwork study, it is possible to distinguish two main different types of schist in the study area. The first type of schist stone (T1), see Figure 3, the most abundant and used, is characterized by having very well defined anisotropic planes, a very smooth surface and a homogeneous aspect, in ochre and very bright color. It is a stone that easily breaks into layers and it is very easily prepared and work in place. Due to these characteristics, the masonry units obtained have an average size of around $0.4 \times 0.3 \times 0.5 \mathrm{~m}^{3}$, generally of rectangular proportion and parallel to its anisotropy plans' direction, and also small units or very thin wedges. If not sawn, these masonry units are always irregular in the vertical planes and more regular in the horizontal ones. If available, larger and more regular units were sometimes used to reinforce fragile points.

The second type of schist stone (T2), see Figure 3, only exists in the northeastern part of the study area and it is less abundant. It has very irregular and sometimes undetectable anisotropic planes, which can have different directions inside the same stone, a higher percentage of internal voids and fracture lines. In global terms, it is more heterogeneous showing a more complex mineral composition, and the surfaces are rough and in browns, reds and ferrous colors. It has a more complex extraction and preparation process due to its unpredictable internal structure. In spite of that, it is a harder stone than the T1 schist, stiffer and allowing the extraction of larger and longer units, allowing the production of ashlar stones to reinforce weak points and openings.

It was common to build masonry fabrics with T1 schist and use T2 schist to reinforce them. Large blocks were shaped in parallelepiped form, but smaller units had irregular shapes and it was not possible to obtain thin wedges.

Due to schist units' irregularities, and except for the mentioned dry joint walls, the use of bedding mortars was fundamental to help build more resistant and higher masonry walls. The mortars used, see Figure 4, were made with the materials 

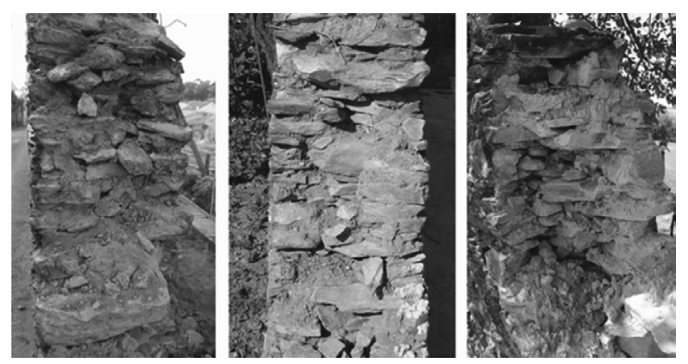

Figure 4. Examples of schist masonries' sections with different bedding mortar. From left to right: soil; saibro; sand with kaolin clay (C.E. Barroso et al.).

available locally, namely clay soil, and had a very low binding capability (Barroso 2012).

The mortar could be simple soil, generating a dark brown and dusty filling of the wall, mixes of sand and clay, generating a more binding orange mortar when using saibro, or more dusty and brown mortar when using clay or barro, or sand with kaolin clay, originating a white, stiffer and more resistant mortar. Different building stages could originate masonry sections with different mortars and different masonry performances in the same wall. More elaborated walls could have mixtures of local sands and imported lime. Plasters were not applied in these kinds of walls.

\subsection{The building process}

Small or average height walls were frequently built directly by farmers, resulting frequently in less quality masonry's fabrics, while high walls were generally built or had assistance from masons, resulting in higher quality masonry's fabrics with the use of ashlar stones reinforcements and more elaborated capstones' works. The following constructive description refers to a high masonry wall, see Figure 5 , and was gather by observations on site and testimonies from professional masons. It describes the building fundaments of almost all masonries of the study area. The vernacular masonry walls studied were composed of two leaves, built using mainly T1 schist stone with randomly applied reinforcement stones from $\mathrm{T} 2$ schist.

The building of this kind of walls was made by stretches and was composed of three stages. The first stage corresponded to the built of a shallow foundation, $0.3 \mathrm{~m}$ deep and $0.1 \mathrm{~m}$ wide to each side of the wall, using small or average schist stones from the same type of the wall (Freitas 2012). This foundation could be continuous or between the existing bedrock.

In the second stage, a double-leaf masonry enclosing a ruble core would be built by the use of
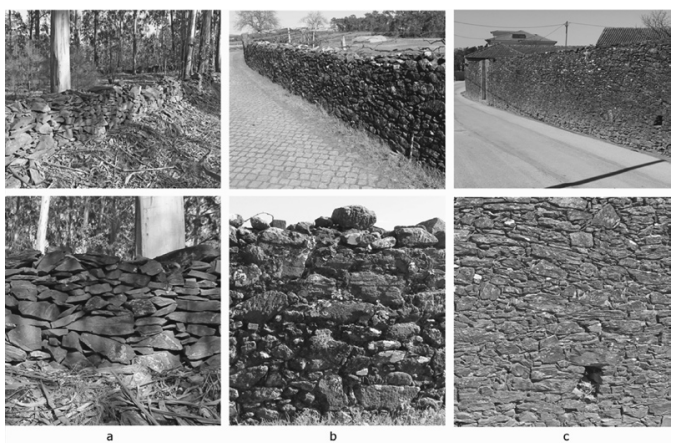

Figure 5. Examples of schist vernacular masonry walls: (a) small height dry joint $\mathrm{T} 1$ schist masonry wall; (b) average height T2 schist masonry wall; (c) high T1 schist masonry with T2 schist reinforcements masonry wall. (C.E. Barroso et al.).

leveling guidelines or/and timber framed structures to raise and level the vertical plane, and timber scaffolding to allow building the wall's higher levels.

The building of the vertical plane could occur in sections by horizontal layers, leaving visible horizontal joints between different levels, or in vertical sections, using a diagonal joint at the end of each stretch to allow attaching the fallowing one.

The third and last stage consisted in the building of the capstones and on the filling, frequently only on the external side of the property, of any remaining gaps and voids in the fabric, using wedges and small schist units.

The masonry fabric built was composed of schist units bounded with mortar following the same principles of farmhouses' masonry walls (Barroso et al. 2013), but with considerable inferior quality and presenting a high number of voids and irregularities.

The leaves were composed of average size T1 schist of approximately parallelepiped shape units, laid down always in the parallel direction of its anisotropic planes, and with the most regular face to the external side of the wall. The bigger stones were leveled by the use of bedding mortar and of smaller stones and wedges. The smaller stones sometimes were just randomly laid down to fill in gaps between big stones. Large T2 schist stones were also used when available. Due to their weight and the difficulty in raising them to higher levels, the large units were placed at the bottom, reinforcing the base of the wall.

To increase wall's cohesion, the stone units would overlap at the core, and opposing leaves would be connected by the use of regular or irregular transversal stones or by units penetrating in the core. The core would be filled with ruble and small stones. 

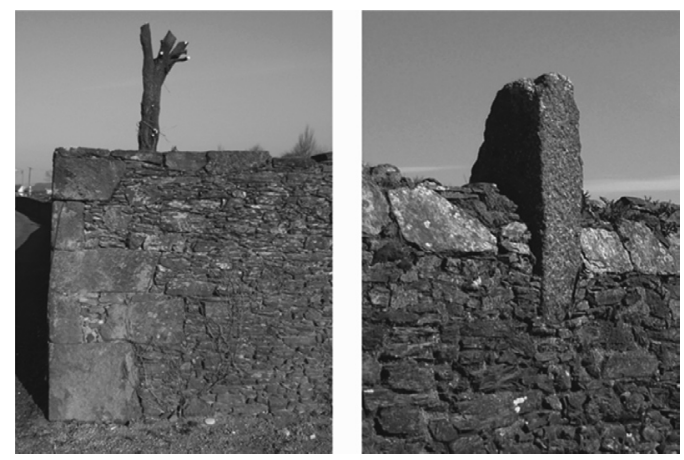

Figure 6. Examples of corner's reinforcement in T2 schist stone. Example of elaborated capstone with grapevines' structure. (C.E. Barroso et al.).

Average sections had $0.5 \mathrm{~m}$ wide in less quality construction, and reducing from base to top from $0.6 \mathrm{~m}$ to $0.4 \mathrm{~m}$ wide in higher quality masonries. This contributed to stabilized the wall and rationalize the use of material on walls of over $2 \mathrm{~m}$. The reinforcement of wall's fragile points like corners, openings and the attaching to other walls, see Figure 6, were frequently built in T2 schist stone, and following the same principles of farmhouses' masonries (Barroso et al. 2013).

The dry masonry walls, see Figure 5, were built using stones gathered in the forestall property they limited, and presented heights from $0.4 \mathrm{~m}$ to $1.2 \mathrm{~m}$, and thickness ranging from $0.4 \mathrm{~m}$ to $0.6 \mathrm{~m}$. These walls had no foundation and the schist stone units used, generally small and some average size T1 schist, were geometrical adjusted in site and laid down in horizontal layers, one layer in the longitudinal direction of the wall, the following on its transversal direction, helping to reinforce both leaves.

The core was filled with very small stone units. The masonry fabric's quality was very weak, in result of the very low binding between stones and a very high number of voids, resulting in a very low wall's cohesion and on its fragile stability.

Better quality masonries had a reduced number of voids and had capstones, whereas in the lowest quality wall, the masonry's fabric was the result of the stones stacking without special binding cares.

The only kind of one-leaf wall observed during the fieldwork study, see Figure 7, was composed of $0.1 \mathrm{~m}$ thick slabs of schist of variable dimensions, placed in a vertical position, and forming an alignment of stones to establish a limit.

These were short walls and their height depended on the sizes of the slabs, which varied from $0.6 \mathrm{~m}$ when laid sideways or $1 \mathrm{~m}$ when laid in a vertical position. This kind of wall was an exception and is not frequent in the study area.

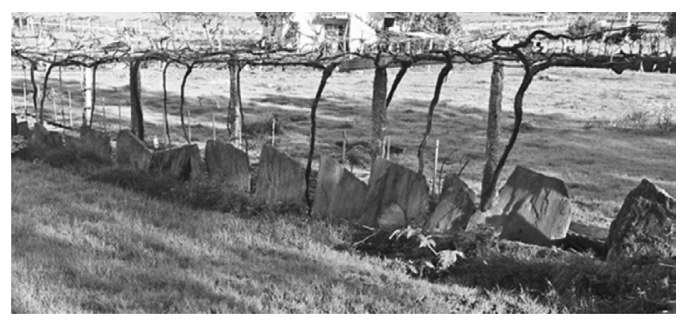

Figure 7. Example of one leave wall built in T1 schist slabs. (C.E. Barroso et al.).

\section{PRESERVATION RECOMMENDATIONS}

The preservation of this fragile heritage, of its diversity and of its landscape value, faces considerable threats. The loss of use of most rural buildings due to the abandonment of the rural areas reduces significantly maintenance and repair of its structures, leading eventually to their ruin and destruction. Progressively, the lack of memory and the loss of vernacular construction knowledge opens the way to the substitution of vernacular models and construction materials by industrial ones, making them natural in the collective memory (Oliveira et al. 1992). In the study area, the absence of operational schist quarries, the almost absence of experienced masons, along with the excessive specialization of local construction industry in nontraditional and concrete-based solutions, increases the costs of building of such kind of walls.

In order to protect and preserve this kind of vernacular heritage, different levels of actions are needed and multidisciplinary approaches are vital (ICOMOS, 2001). New landscape policies, which take in account the rural way of life and its economical value, are fundamental to stop rural abandonment. In the same context, it is also fundamental a new building legislative framework, that takes in account the specificities of vernacular heritage, in order to absorb all constructive diversity that do not fit in the current codes. The study of still existent vernacular masonry walls is also very relevant in the process of protecting and even regaining lost knowledge. The availability of knowledge is fundamental to assist technicians to make more effective preservation interventions with proper materials and techniques. These should be within the best practices of preservation and intervention orientated by principles of physical and chemical compatibility between materials, of reversibility and durability (ICOMOS 2001). Considering that the present context of the study area is very different from vernacular context, new interpretations of vernacular solutions, if necessary with the help of new solutions, may allow solving contemporary 


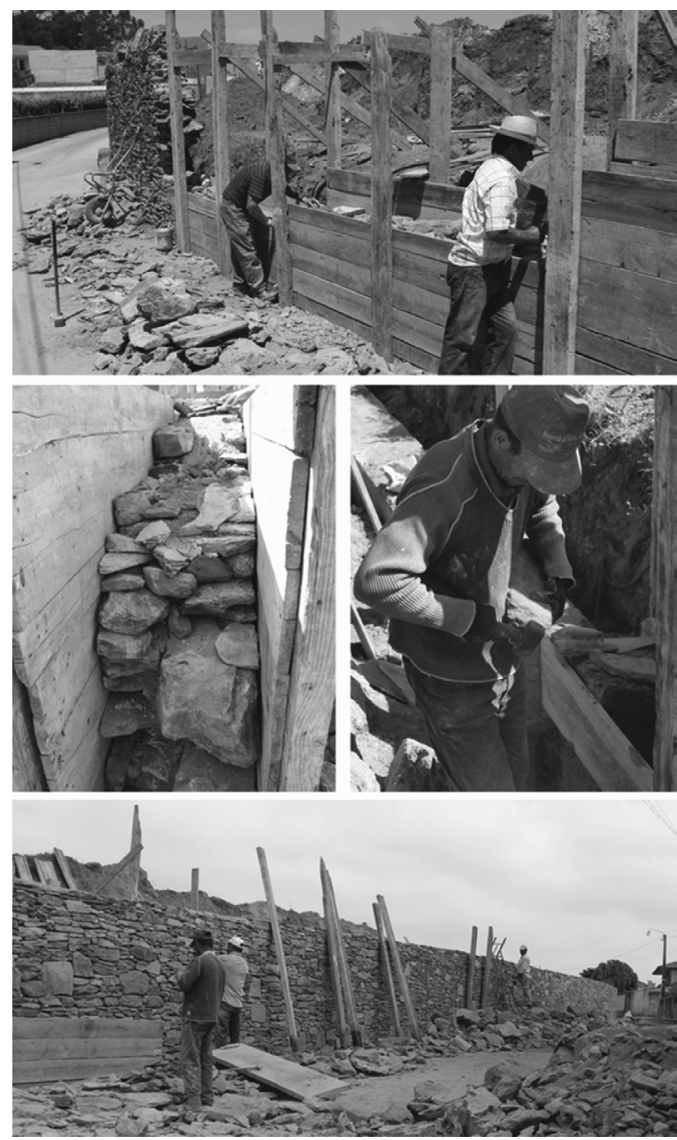

Figure 8. Example of high schist masonry wall rebuilding. (C.E. Barroso et al.).

problems like the introduction of modern infrastructures, or even to reduce seismic risk (Roque 2002). The spreading of vernacular building knowledge by local technicians and general population, making local communities to regain their sense of rural identity and the means to take care of their own heritage, can give a decisive contribution to vernacular heritage protection and preservation (ICOMOS 1982).

\section{CONCLUSIONS}

Vernacular schist masonry walls are one of the most valuable heritage of the Portuguese northwestern rural landscape. Their protection constitutes not only an historical preservation of its technological and constructive diversity, but also the memory of the construction of a landscape and of the effort of generations to make it more suitable to suppress human needs. Preserving this way of building also contributes to the sustainability of local economy by using local environmental friendly construction materials, using less mechanical means and allowing local populations to better maintain and rebuild their own heritage by their own means.

\section{ACKNOWLEDGEMENTS}

The first author wish to express his gratitude to the Portuguese Science and Technology Foundation for the scholarship granted (SFRH/BD/ 86704/2012).

\section{REFERENCES}

Barros, R.S. et al. 2014. Experimental characterization of physical and mechanical properties of schist from Portugal. Construction and Building Materials, 50: 617-630.

Barroso, C.E. 2012. A construção vernacular em xisto entre o Cávado e o Ave-o caso de Barqueiros. Universidade do Minho. Retrieved from http://hdl.handle. net $/ 1822 / 24780$

Barroso, C.E. et al. 2013. The vernacular house between the Cávado and the Ave, Portugal. In Coreia, Carlos, \& Rocha (Eds.), CIAV2013 (pp. 351-357). Vila Nova de Cerveira: Taylor \& Francis. Retrieved from http://hdl. handle.net/1822/26820

Costa, J.B. 2008. Estudo e classificação das rochas por exame macroscópico $\left(11^{\mathrm{a}}\right.$ ed., p. 196). Lisboa: Fundação Calouste Gulbenkien-Serviço de Educação e Bolsas.

Freitas, V.P. 2012. Manual de Apoio ao Projecto de Reabilitação de Edificios Antigos. Porto: OERN.

ICOMOS. 1982. Tlaxcala Declaration on the Revitalization of Small Settlements (pp. 6-8). Tlaxcala.

ICOMOS. 2001. Recommendations for the analysis, conservation and structural restoration of architectural heritage. Paris

Monteiro, M. 2000. 1.Marcas arquitectónicas do "Brasileiro" na paisagem do minho. O Brasileiro de Torna Viagem (pp. 1-21). Lisboa: Comissão Nacional para as Comemorações dos Descobrimentos Portugueses.

Oliveira, E.V. de, \& Galhano, F. 1992. Arquitectura Tradicional Portuguesa (4 ${ }^{\mathrm{a}}$ ed., p. 374). Lisboa:Publicações Dom Quixote.

Ribeiro, O. 1945. Portugal, o Mediterrâneo e o Atlântico. Coimbra, Editora Limitada (p. 245). Coimbra: Coimbra Editora. Retrieved from http://purl.pt/421.

Saraiva, C. 1994. Contrastes do Alto Minho: a Ribeira e a Serra. Cadernos Vianenses, 172-192.

Roque, J. 2002. Reabilitação estrutural de paredes antigas de alvenaria. Universidade do Minho. Retrieved from http://bibliotecadigital.ipb.pt/handle/10198/1724. 